\title{
Towards an electronic dictionary of Tamajaq language in Niger
}

\author{
Chantal Enguehard \\ LINA - UMR CNRS 6241 \\ 2, rue de la Houssinière \\ BP 92208 \\ 44322 Nantes Cedex 03 \\ France
chantal enguehardeuniv-
nantes.fr

\author{
Issouf Modi \\ Ministère de l'Education Nationale \\ Direction des Enseignements du Cycle \\ de Base1 \\ Section Tamajaq. \\ Republique du Niger \\ modyissoufeyahoo.fr
}

\begin{abstract}
We present the Tamajaq language and the dictionary we used as main linguistic resource in the two first parts. The third part details the complex morphology of this language. In the part 4 we describe the conversion of the dictionary into electronic form, the inflectional rules we wrote and their implementation in the Nooj software. Finally we present a plan for our future work.
\end{abstract}

\section{The Tamajaq language}

\subsection{Socio-linguistic situation}

In Niger, the official language is French and there are eleven national languages. Five are taught in a experimental schools: Fulfulde, Hausa, Kanuri, Tamajaq and Sonay-Zarma. According to the last census in 1998, the Tamajaq language is spoken by $8,4 \%$ of the 13.5 million people who live in Niger. This language is also spoken in Mali, Burkina-Faso, Algeria and Libya. It is estimated there are around 5 millions Tamajaq-speakers around the world.

The Tamacheq language belongs to the group of Berber languages.

\subsection{Tamajaq alphabet}

The Tamajaq alphabet used in Niger (Republic of Niger, 1999) uses 41 characters, 14 with diacritical marks that all figure in the Unicode standard (See appendix A). There are 12 vowels: a, â, ă, ə, e, ê, i, î, o, ô, u, û.

\subsection{Articulatory phonetics}

\begin{tabular}{|c|c|c|c|}
\hline \multicolumn{2}{|l|}{ Consonants } & \multirow[t]{2}{*}{ Voiceless } & \multirow{2}{*}{\begin{tabular}{|l} 
Voiced \\
b
\end{tabular}} \\
\hline Bilabial & Plosive & & \\
\hline & Nasal & & $\mathrm{m}$ \\
\hline & Trill & & $r$ \\
\hline & Semivowel & & w \\
\hline Labiodental & Fricative & $\mathrm{f}$ & \\
\hline \multirow[t]{4}{*}{ Dental } & Plosive & $\mathrm{t}$ & d \\
\hline & Fricative & $\mathrm{S}$ & Z \\
\hline & Nasal & & $\mathrm{n}$ \\
\hline & Lateral & & 1 \\
\hline \multirow[t]{3}{*}{ Pharyngeal } & Plosive & $t$ & d \\
\hline & Fricative & S & $z$ \\
\hline & Lateral & & ! \\
\hline Palatal & Plosive & c & ǰ \\
\hline
\end{tabular}


Enguehard, C., Modi I. Towards an electronic dictionary of Tamajaq language in Niger. 12th Conference of the European Chapter of the Association for Computational Linguistics EACL-09. W07 Workshop Language Technologies for African Languages. Athens, Greece, 31 March 2009.

\begin{tabular}{|l|l|l|l|}
\hline \multicolumn{2}{|l|}{ Consonants } & Voiceless & Voiced \\
\hline \multirow{4}{*}{} & Fricative & š & $\mathrm{j}$ \\
\cline { 2 - 4 } & Semivowel & & $\mathrm{y}$ \\
\hline \multirow{4}{*}{ Gelar } & Plosive & $\mathrm{k}$ & $\mathrm{g}, \breve{\mathrm{g}}$ \\
\cline { 2 - 4 } & Fricative & $\mathrm{\gamma}$ & $\mathrm{x}$ \\
\cline { 2 - 4 } & Nasal & & $\mathrm{y}$ \\
\hline & Plosive & $\mathrm{q}$ & \\
\cline { 2 - 4 } & Fricative & $\mathrm{h}$ & \\
\hline
\end{tabular}

Table 1a: Articulatory phonetics of Tamajaq consonants

\begin{tabular}{|l|l|l|l|l|}
\hline Vowels & Close & Close-mid & Open-mid & Open \\
\hline Palatal & $\mathrm{i}$ & $\mathrm{e}$ & & \\
\hline Central & & ə & ă & $\mathrm{a}$ \\
\hline Labial & $\mathrm{u}$ & $\mathrm{o}$ & & \\
\hline
\end{tabular}

Table 1b: Articulatory phonetics of Tamajaq vowels

\subsection{Tools on computers}

There are no specific TALN tools for the Tamajaq language.

However characters can be easily typed on French keyboards thanks to the AFRO keyboard layout (Enguehard and al. 2008).

\section{Lexicographic resources}

We use the school editorial dictionary "dictionnaire Tamajaq-français destiné à l'enseignement du cycle de base 1". It was written by the SOUTEBA $^{1}$ project of the $\mathrm{DED}^{2}$ organisation in 2006. Because it targets children, this dictionary consists only of 5,390 entries. Words have been chosen by compiling school books.

\subsection{Structure of an entry}

Each entry generally details :

- lemma,

- lexical category,

- translation in French,

- an example,

- gender (for nouns),

${ }^{1}$ Soutien à l'éducation de base.

${ }^{2}$ DED: Deutscher Entwicklungsdienst.
- plural form (for nouns).

\section{Examples:}

« ăbada ${ }_{1}$ : sn. bas ventre. Daw tədist. Bărar wa yəllûzăn ad t-yəltəy ăbada-net. təmust.: yy. igət: ibadan. »

«ăbada2: sn. flanc. Tasăga mey daw ădăg əyyăn. Iməwwəzla əklăn dăy ăbada $n$ əkašwar. Anammelu.: azador. təmust.: yy. ヨsəfsəs.: ă. Igət: ibadan. »

Homonyms are described in different entries and followed by a number, as in the above example.

\subsection{Lexical categories}

The linguistic terms used in the dictionary are written in the Tamajaq language using the abbreviations presented in table 2 . In addition, this table gives information about the number of entries of each lexical category.

\begin{tabular}{|c|c|c|c|}
\hline \multicolumn{2}{|c|}{ Lexical category } & \multirow{2}{*}{$\begin{array}{c}\text { Abbrevi- } \\
\text { ation }\end{array}$} & \multirow{2}{*}{\begin{tabular}{|c|} 
Number \\
of entries
\end{tabular}} \\
\hline Tamajaq & English & & \\
\hline əḍ̂kuọ & number & ḍkd. & 3 \\
\hline әnalkam & deteminant & nlkm. & 1 \\
\hline anamal & verb & $\mathrm{nml}$. & 1450 \\
\hline samal & adjective & sml. & 48 \\
\hline $\begin{array}{l}\text { əsəmmadăy ən } \\
\text { təla }\end{array}$ & $\begin{array}{l}\text { possessive } \\
\text { pronoun }\end{array}$ & smmdytl. & 5 \\
\hline isən & noun & sn. & 3648 \\
\hline isən n ənamal & Verbal noun & snnml. & 33 \\
\hline isən an təyərit & $\begin{array}{l}\text { name of } \\
\text { shout }\end{array}$ & sntyrt. & 2 \\
\hline isən xalalan & proper noun & snxln. & 29 \\
\hline isən izzz̧əwen & $\begin{array}{l}\text { complex } \\
\text { noun }\end{array}$ & snẓwn. & 137 \\
\hline əstakar & adverb & stkr. & 8 \\
\hline
\end{tabular}


Enguehard, C., Modi I. Towards an electronic dictionary of Tamajaq language in Niger. 12th Conference of the European Chapter of the Association for Computational Linguistics EACL-09. W07 Workshop Language Technologies for African Languages. Athens, Greece, 31 March 2009.

\begin{tabular}{|l|l|l|l|}
\hline əsatkar $n$ ădag & $\begin{array}{l}\text { adverb of } \\
\text { location }\end{array}$ & stkrdg. & 10 \\
\hline əșatkar $n$ igət & $\begin{array}{l}\text { Adverb of } \\
\text { quantity }\end{array}$ & stkrgt. & 1 \\
\hline tə̧ərit & $\begin{array}{l}\text { onomato- } \\
\text { poeia }\end{array}$ & tyrt. & 8 \\
\hline tənalkamt & particle & tnlkmt. & 2 \\
\hline
\end{tabular}

Table 2: Tamajaq lexical categories

\section{Morphology}

The Tamajaq language presents a rich morphology (Aghali-Zakara, 1996).

\subsection{Verbal morphology}

Verbs are classified according to the number of consonants of their lexical root and then in different types. There are monoliteral, biliteral triliteral, quadriliteral verbs...

Three moods are distinguished: imperative, simple injunctive and intense injunctive.

Three aspects present different possible values:

- accomplished: intense or negative;

- non accomplished: simple, intense or negative;

- aorist future: simple or negative.

\section{Examples :}

əktəb (to write): triliteral verb, type 1.

əșṣən (to know): triliteral verb, type 2 (șṣn).

әməl (to say): biliteral verb, type 1

akər (to steal): biliteral verb, type 2

awəy (to carry): biliteral verb, type 3

ǎšwu (to drink): biliteral verb, type 4

ăru (to love): monoliteral verb, type 2

ăru (to open): monoliteral verb, type 3

Each class of verb has its own rules of conjugation.

\subsection{Nominal morphology}

\section{a. Simple nouns}

Nouns present three characteristics:

- gender: masculine or feminine;
- number: singular or plural;

- annexation state is marked by the change of the first vowel.

\begin{tabular}{|l|l|l|}
\hline \multicolumn{2}{|c|}{ Terminology } & Abbreviation \\
\hline təmust & gender & tmt. \\
\hline yey & masculine & yy. \\
\hline tənte & feminine & tnt. \\
\hline awdəkki & singular & wdk. \\
\hline iget & plural & gt. \\
\hline əsəfsəs & $\begin{array}{l}\text { annexation } \\
\text { state }\end{array}$ & sfss. \\
\hline
\end{tabular}

Table 3: Tamajaq terminology for nouns

Example :

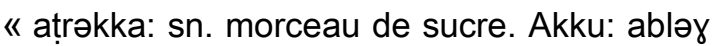
n². təmust.: yy. $\exists$ səfsəs.: ə. lgət: əțrəkkatăn. "

"atrrəkka" is a masculine noun. Its plural is "əțrəkkatăn". It becomes "əțrəkka" when annexation state is expressed.

The plural form of nouns is not regular and has to be specifically listed.

\section{b. Complex nouns}

Complex nouns are composed by several lexical units connected together by hyphens. It could include nouns, determiners or prepositions as well as verbs.

Examples:

Noun +determiner + noun

"ejăḍ-n-əjḍăn", literally means "donkey of birds" (this is the name of a bird).

Verb + noun

"awəy-əhud" literally means "it follows harmattan" (kite).

"gazzzăy-təfuk" literally means "it looks at sun" (sunflower).

Preposition + noun

"In-tamat" means "the one of the tree acacia" (of acacia).

Verb + verb 
Enguehard, C., Modi I. Towards an electronic dictionary of Tamajaq language in Niger. 12th Conference of the European Chapter of the Association for Computational Linguistics EACL-09. W07 Workshop Language Technologies for African Languages. Athens, Greece, 31 March 2009.

"azəl-azəl" means "run run" (return).

We counted 238 complex nouns in the studied dictionary.

\section{Natural Language Processing of Tamajaq}

\subsection{Nooj software (Silberztein, 2007)}

« Nooj is a linguistic development environment that includes tools to create and maintain largecoverage lexical resources, as well as morphological and syntactic grammars. » This software is specifically designed for linguists who can use it to test hypothesis on real corpus. " Dictionaries and grammars are applied to texts in order to locate morphological, lexical and syntactic patterns and tag simple and compound words. » Nooj put all possible tags for each token or group of tokens but does not disambiguate between the multiple possibilities. However, the user can build his own grammar to choose between the multiple possible tags. The analysis can be displayed as a syntactic tree.

This software is supported by Windows.

We chose to construct resources for this software because it is fully compatible with Unicode.

\subsection{Construction of the dictionary}

We convert the edited dictionary for the Nooj software.

3,463 simple nouns, 128 complex nouns, 46 adjectives and 33 verbo-nouns are given with their plural form. Annexation state is indicated for 987 nouns, 23 complex nouns, 2 adjectives and 7 verbo-nouns.

We created morphological rules that we expressed as Perl regular expressions and also in the Nooj format (with the associated tag).

\section{a. Annexation state rules}

Thirteen morphological rules calculate the annexation state.

Examples:

The 'Ală' rule replaces the first letter of the word by 'ă'.

\begin{tabular}{|l|l|}
\hline \multicolumn{2}{|c|}{ 'Ală' rule } \\
\hline Nooj & $<\mathrm{LW}><\mathrm{S}>\mathrm{a} / \mathrm{sfss}$ \\
\hline Perl & $\wedge .\left(.^{*}\right) \$ \rightarrow \breve{a} \$ 1$ \\
\hline \multicolumn{2}{|c|}{ Table 4: Rule 'Ală' }
\end{tabular}

The 'A2 ${ }^{\prime}$ ' rule replaces the second letter of the word by ' $ə$ '.

\begin{tabular}{|l|l|}
\hline \multicolumn{2}{|c|}{ 'A2 $\vartheta^{\prime}$ rule } \\
\hline Nooj & A2 $ə=<\mathrm{LW}><\mathrm{R}><\mathrm{S}>\partial /$ sfss \\
\hline Perl & $\wedge(.) .\left(.^{*}\right) \$ \rightarrow \$ 1 ə \$ 2$ \\
\hline \multicolumn{2}{|c|}{ Table 5: Rule 'A2 $\vartheta^{\prime}$}
\end{tabular}

\section{b. Plural form rules}

We searched formal rules to unify the calculation of plural forms. We found 126 rules that fit from 2 up to 446 words. 2932 words could be associated with, at least, one flexional rule.

Examples:

'I4' rule deletes the last letter, adds "-ăn" at the end and "i-" at the beginning.

\begin{tabular}{|l|l|}
\hline Nooj & $\mathrm{I} 4=$ ăn $<\mathrm{LW}><\mathrm{S}>\mathrm{i} /$ Iget \\
\hline Perl & $\wedge\left({ }^{*}\right) . \$ \rightarrow \mathrm{i} \$ 1$ ăn \\
\hline$\#$ & 446 words \\
\hline
\end{tabular}

Table 6: Rule 'I4'

'I2' rule deletes the last and the second letters and includes "-en" at the end and "-i-" in the second position.

\begin{tabular}{|l|l|}
\hline Nooj & $\mathrm{I} 2=<\mathrm{B}>$ en $<\mathrm{LW}><\mathrm{R}><\mathrm{S}>\mathrm{i} /$ Iget \\
\hline Perl & $\wedge() ..\left(.^{*}\right) . \$ \rightarrow \$ 1$ 1i 2 en \\
\hline$\#$ & 144 words \\
\hline
\end{tabular}

Table 7: Rule 'I2'

\begin{tabular}{|c|c|}
\hline Nooj & I $45=<\mathrm{B}>$ en $/$ Iget \\
\hline Perl & $\wedge\left(.^{*}\right) . \$ \rightarrow \$ 1$ en \\
\hline \# & 78 words \\
\hline
\end{tabular}

Table 8: Rule 'I45' 
Enguehard, C., Modi I. Towards an electronic dictionary of Tamajaq language in Niger. 12th Conference of the European Chapter of the Association for Computational Linguistics EACL-09. W07 Workshop Language Technologies for African Languages. Athens, Greece, 31 March 2009.

'I102' rule deletes the two last letters and the second one and includes a final "-a" and a "-i-" in the second position.

\begin{tabular}{|l|l|}
\hline Nooj & $\mathrm{I} 102=<\mathrm{B} 2>\mathrm{a}<\mathrm{LW}><\mathrm{R}><\mathrm{S}>\mathrm{i} /$ Iget \\
\hline Perl & $\wedge$ (.).(.*)..\$ $\rightarrow \$ 1 \mathrm{i} \$ 2 \mathrm{a}$ \\
\hline$\#$ & 6 words \\
\hline
\end{tabular}

Table 9: Rule 'I102'

\section{c. Combined rules}

When it was necessary, the above rules have been combined to calculate singular and plural forms with or without annexation state.

We thus finally obtained 319 rules.

Example:

I2RA2 $\breve{a}=$

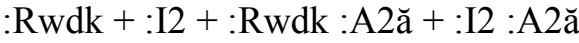

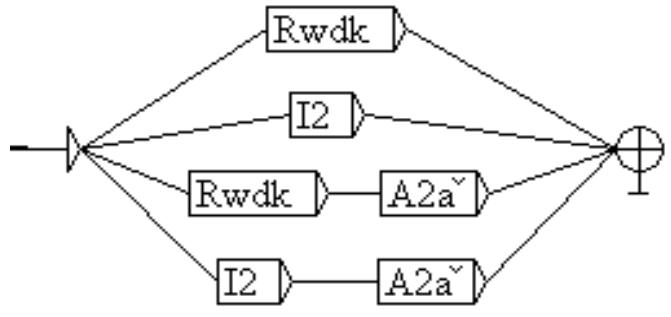

Fig. 1: Rule I2RA2ă

This rule recognizes the singular form (:Rwdk), the plural form (:I2), the singular form with the annexation state (:Rwdk :A2ă) and the plural form with the annexation state (:I2 :A2ă).

25 words meet this rule.

For instance, "taḍləmt" (accusation, provocation), is inflected in:

- tadiləmt,tadləmt,SN+tnt+wdk

- tiḍləmen,taḍləmt,SN+tnt+Iget

- tăḍləmen,taḍləmt,SN+tnt+Iget+sfss

- tăḍləmt,taḍləmt,SN+tnt+wdk+sfss

\section{d. Conjugaison rules}

Verb classes are not indicated in the dictionary. We only describe a few conjugaison rules, just to check the expressivity of the Nooj software

Here is the rule of the verb "əșșən" (to know), intense accomplished aspect, represented as a transducer.

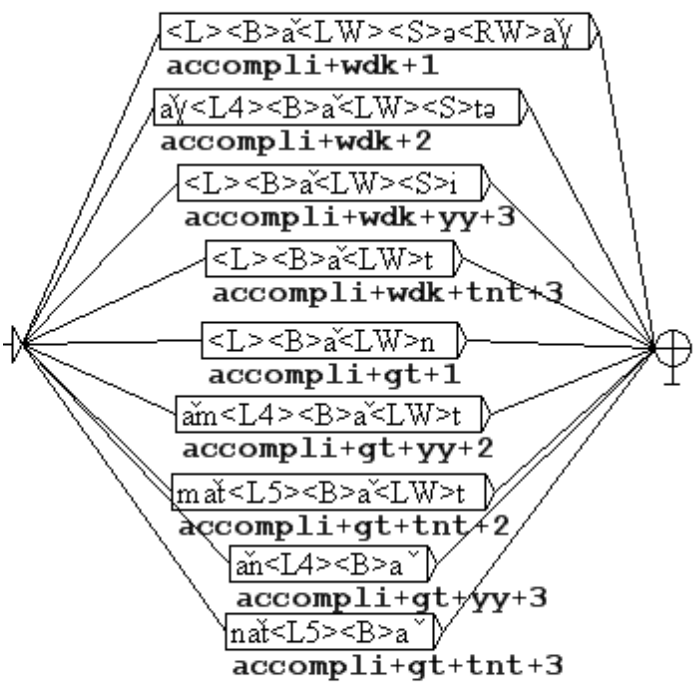

Fig. 2: Verb "əșșən", intense accomplished aspect

We obtain, in the inflected dictionary, the correct conjugated forms.

$$
\begin{aligned}
& \text { əșșănăy+əșșən, } \mathrm{V}+\mathrm{accompli}+\mathrm{wdk}+1 \\
& \text { təșṣănăy+əșṣən, } \mathrm{V}+\mathrm{accompli}+\mathrm{wdk}+2 \\
& \text { ișșăn+əșșən, } \mathrm{V}+\mathrm{accompli}+\mathrm{wdk}+\mathrm{yy}+3 \\
& \text { təșșăn+əșșən, } \mathrm{V}+\mathrm{accompli}+\mathrm{wdk}+\mathrm{tnt}+3 \\
& \text { nəșṣăn+əșșən, } \mathrm{V}+\mathrm{accompli}+\mathrm{gt}+1 \\
& \text { təșșănăm+əșșən, } \mathrm{V}+\mathrm{accompli}+\mathrm{gt}+\mathrm{yy}+2 \\
& \text { təșșănmăt+əșṣən, } \mathrm{V}+\mathrm{accompli}+\mathrm{gt}+\mathrm{tnt}+2 \\
& \text { əș̣̦ănăn+əșșən, } \mathrm{V}+\mathrm{accompli}+\mathrm{gt}+\mathrm{yy}+3 \\
& \text { əșșănnăt+əșșən, } \mathrm{V}+\mathrm{accompli}+\mathrm{gt}+\mathrm{tnt}+3
\end{aligned}
$$

\section{e. Irregular words}

Finally, the singular and plural forms of 2,457 words were explicitly written in the Nooj dic- 
Enguehard, C., Modi I. Towards an electronic dictionary of Tamajaq language in Niger. 12th Conference of the European Chapter of the Association for Computational Linguistics EACL-09. W07 Workshop Language Technologies for African Languages. Athens, Greece, 31 March 2009.

tionary because they do not follow any regular rule.

Examples:

\begin{tabular}{|l|l|l|}
\hline Singular & Plural & Translation \\
\hline ag-awnaf & kel-awnaf & tourist \\
\hline amanẓo & imenz̧a & young animal \\
\hline ănaffarešši & inəffərəšša & $\begin{array}{l}\text { someboby with } \\
\text { bad mood }\end{array}$ \\
\hline ănesbehu & inəsbuha & liar \\
\hline efange & ifangăyan & bank \\
\hline efajanfăj & ifajanfăyăn & sling \\
\hline emagărmăz & imagămăzăn & plant \\
\hline emazzăle & imazzaletăn & singer \\
\hline taḍaggalt & tiḍlen & $\begin{array}{l}\text { daughter-in- } \\
\text { law }\end{array}$ \\
\hline tejăț & tizḍen & goal (football) \\
\hline \multicolumn{2}{|l|}{ Table 10: Examples of irregular plural forms }
\end{tabular}

\section{f. Result}

There are 6,378 entries in the Nooj dictionary. The inflected dictionary, calculated from the above dictionary and with the inflectional and conjugation rules, encounters 11,223 entries.

Nooj is able to use the electronic dictionary we've created to automatically tag a text (see an example in appendix B).

\subsection{Future work}

\section{a Conversion into XML format}

We will convert the inflectional dictionary into the international standard Lexical Markup Framework format (Francopoulo and al., 2006) in order to make it easily usable by other TALN application,.

\section{b Automatic search of rules}

Due to the high morphological complexity of the Tamajaq language, we plan to develop a Perl program that would automatically determine the derivational and conjugation rules.

\section{c Completion and correction of the resource}

The linguistic resource will be completed during the next months in order to add the class of verbs that are absent for the moment, and also to correct the errors that we noticed during this study.

\section{d Enrichment of the resource}

We plan to construct a corpus of school texts to evaluate the out-of-vocabulary rate of this dictionary. This corpus could then be used to enrich the dictionary. The information given by Nooj would be useful to choose the words to add.

\section{Acknowledgement}

Special thanks to John Johnson, reviewer of this text.

\section{References}

Aghali-Zakara M. 1996. Éléments de morphosyntaxe touarègue. Paris : CRB-GETIC, $112 \mathrm{p}$.

Enguehard C. and Naroua H. 2008. Evaluation of Virtual Keyboards for West-African Languages. Proceedings of the Sixth International Language Resources and Evaluation (LREC'08), Marrakech, Morocco.

Francopoulo G., George M., Calzolari N., Monachini M., Bel N., Pet M., Soria C. 2006 Lexical Markup Framework (LMF). LREC, Genoa, Italy.

République of Niger. 19 octobre 1999. Arrêté 21499 de la République du Niger.

Max Silberztein. 2007. An Alternative Approach to Tagging. NLDB 2007: 1-11 
Enguehard, C., Modi I. Towards an electronic dictionary of Tamajaq language in Niger. 12th Conference of the European Chapter of the Association for Computational Linguistics EACL-09. W07 Workshop Language Technologies for African Languages. Athens, Greece, 31 March 2009.

APPENDIX A : Tamajaq official alphabet (République of Niger, 1999)

\begin{tabular}{|c|c|c|c|}
\hline Character & Code & Character & Code \\
\hline $\mathrm{a}$ & $\mathrm{U}+0061$ & A & $\mathrm{U}+0041$ \\
\hline$\hat{a}$ & $\mathrm{U}+00 \mathrm{E} 1$ & $\hat{A}$ & $\mathrm{U}+00 \mathrm{C} 2$ \\
\hline$\breve{a}$ & $\mathrm{U}+0103$ & $\check{A}$ & $\mathrm{U}+0102$ \\
\hline ə & $\mathrm{U}+01 \mathrm{DD}$ & $\exists$ & $\mathrm{U}+018 \mathrm{E}$ \\
\hline $\mathrm{b}$ & $\mathrm{U}+0062$ & $\mathrm{~B}$ & $\mathrm{U}+0042$ \\
\hline $\mathrm{c}$ & $\mathrm{U}+0063$ & $\mathrm{C}$ & $\mathrm{U}+0043$ \\
\hline d & $\mathrm{U}+0064$ & $\mathrm{D}$ & $\mathrm{U}+0044$ \\
\hline d & $\mathrm{U}+1 \mathrm{E} 0 \mathrm{D}$ & D & $\mathrm{U}+1 \mathrm{E} 0 \mathrm{C}$ \\
\hline e & $\mathrm{U}+0065$ & E & $\mathrm{U}+0045$ \\
\hline ê & $\mathrm{U}+00 \mathrm{EA}$ & $\hat{\mathrm{E}}$ & $\mathrm{U}+00 \mathrm{CA}$ \\
\hline $\mathrm{f}$ & $\mathrm{U}+0066$ & $\mathrm{~F}$ & $\mathrm{U}+0046$ \\
\hline g & $\mathrm{U}+0067$ & G & $\mathrm{U}+0047$ \\
\hline ğ & $\mathrm{U}+01 \mathrm{E} 7$ & Ğ & $\mathrm{U}+01 \mathrm{E} 6$ \\
\hline $\mathrm{h}$ & $\mathrm{U}+0068$ & $\mathrm{H}$ & $\mathrm{U}+0048$ \\
\hline $\mathrm{i}$ & $\mathrm{U}+0069$ & I & $\mathrm{U}+0049$ \\
\hline$\hat{\imath}$ & $\mathrm{U}+00 \mathrm{EE}$ & $\hat{I}$ & $\mathrm{U}+00 \mathrm{CE}$ \\
\hline $\mathrm{j}$ & $\mathrm{U}+006 \mathrm{~A}$ & $\mathrm{~J}$ & $\mathrm{U}+004 \mathrm{~A}$ \\
\hline j̆ & $\mathrm{U}+01 \mathrm{~F} 0$ & $\mathrm{~J}$ & $\begin{array}{l}\mathrm{U}+004 \mathrm{AU}+ \\
030 \mathrm{C}\end{array}$ \\
\hline$\gamma$ & $\mathrm{U}+0263$ & $\gamma$ & $\mathrm{U}+0194$ \\
\hline $\mathrm{k}$ & $\mathrm{U}+006 \mathrm{~B}$ & K & $\mathrm{U}+004 \mathrm{~B}$ \\
\hline 1 & $\mathrm{U}+006 \mathrm{C}$ & $\mathrm{L}$ & $\mathrm{U}+004 \mathrm{C}$ \\
\hline$!$ & U+1E37 & 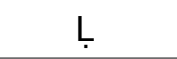 & $\mathrm{U}+1 \mathrm{E} 36$ \\
\hline $\mathrm{m}$ & $\mathrm{U}+006 \mathrm{D}$ & M & $\mathrm{U}+004 \mathrm{D}$ \\
\hline $\mathrm{n}$ & $\mathrm{U}+006 \mathrm{E}$ & $\mathrm{N}$ & $\mathrm{U}+004 \mathrm{E}$ \\
\hline $\mathrm{y}$ & $\mathrm{U}+014 \mathrm{~B}$ & $\mathrm{n}$ & $\mathrm{U}+014 \mathrm{~A}$ \\
\hline o & $\mathrm{U}+006 \mathrm{~F}$ & $\mathrm{O}$ & $\mathrm{U}+004 \mathrm{~F}$ \\
\hline ô & $\mathrm{U}+00 \mathrm{~F} 4$ & Ô & $\mathrm{U}+00 \mathrm{D} 4$ \\
\hline $\mathrm{q}$ & $\mathrm{U}+0071$ & Q & $\mathrm{U}+0051$ \\
\hline $\mathrm{r}$ & $\mathrm{U}+0072$ & $\mathrm{R}$ & $\mathrm{U}+0052$ \\
\hline $\mathrm{s}$ & $\mathrm{U}+0073$ & $\mathrm{~S}$ & $\mathrm{U}+0053$ \\
\hline ș & $\mathrm{U}+1 \mathrm{E} 63$ & Ș & $\mathrm{U}+1 \mathrm{E} 62$ \\
\hline$\check{s}$ & $\mathrm{U}+0161$ & $\check{S}$ & $\mathrm{U}+0160$ \\
\hline $\mathrm{t}$ & $\mathrm{U}+0074$ & $\mathrm{~T}$ & $\mathrm{U}+0054$ \\
\hline
\end{tabular}

\begin{tabular}{|c|c|c|c|}
\hline$t$ & U+1E6D & $T$ & U+1E6C \\
\hline $\mathrm{u}$ & $\mathrm{U}+0075$ & $\mathrm{U}$ & $\mathrm{U}+0055$ \\
\hline$\hat{\mathrm{u}}$ & $\mathrm{U}+00 \mathrm{FB}$ & $\hat{\mathrm{U}}$ & $\mathrm{U}+00 \mathrm{DB}$ \\
\hline $\mathrm{w}$ & $\mathrm{U}+0077$ & $\mathrm{~W}$ & $\mathrm{U}+0057$ \\
\hline $\mathrm{x}$ & $\mathrm{U}+0078$ & $\mathrm{X}$ & $\mathrm{U}+0058$ \\
\hline $\mathrm{y}$ & $\mathrm{U}+0079$ & $\mathrm{Y}$ & $\mathrm{U}+0059$ \\
\hline $\mathrm{z}$ & $\mathrm{U}+007 \mathrm{~A}$ & $\mathrm{Z}$ & $\mathrm{U}+005 \mathrm{~A}$ \\
\hline $\mathrm{z}$ & $\mathrm{U}+1 \mathrm{E} 93$ & $\mathrm{Z}$ & $\mathrm{U}+1 \mathrm{E} 92$ \\
\hline
\end{tabular}


Enguehard, C., Modi I. Towards an electronic dictionary of Tamajaq language in Niger. 12th Conference of the European Chapter of the Association for Computational Linguistics EACL-09. W07 Workshop Language Technologies for African Languages. Athens, Greece, 31 March 2009.

\section{APPENDIX B : Nooj tagging Tamajaq text}

Nooj perfectly recognizes the four forms of the word "awăqqas" (big cat) in the text:

"awăqqas, iwaysan, awaysan"

These forms are listed in the inflectional dictionary as:

awăqqas,awăqqas, $\mathrm{SN}+\mathrm{yy}+\mathrm{wdk}$

awăqqas, awăqqas,SN+yy+wdk+FLX=A1a+sfss

iwaysan,awăqqas, $\mathrm{SN}+\mathrm{yy}+$ iget

awaysan, awăqqas, $\mathrm{SN}+\mathrm{yy}+\mathrm{iget}+\mathrm{FLX}=\mathrm{A} 1 \mathrm{a}+\mathrm{sfss}$

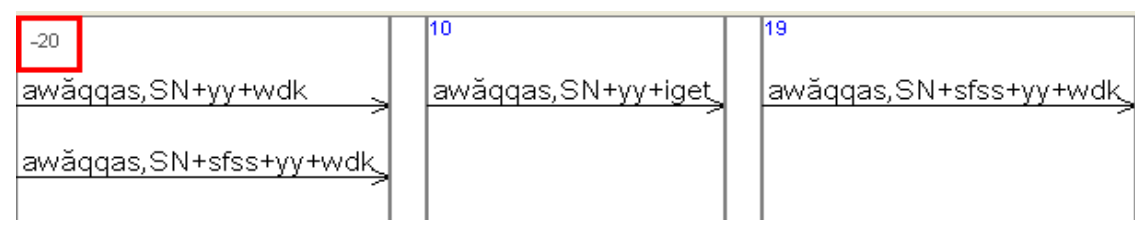

Fig.3: Tags on the text "awăqqas, iwaysan, awaysan"

On the figure 3 , we can see that the first token "awăqqas" gets two tags:

- "awăqqas,SN+yy+wdk" (singular)

- "awăqqas,SN+yy+wdk+sfss" (singular and annexation state).

The second and third tokens get a unique tag because there is no ambiguity. 